\title{
Yayık: Gökhöyük Bağları Höyüğünde Süt ve Süt Ürünleri Üretimine Dair Bir Ön Değerlendirme
}

\author{
Dr. Ramazan Gündüz \\ Selçuk Üniversitesi, Edebiyat Fakültesi \\ Arkeoloji Bölümü \\ ramazangunduz@selcuk.edu.tr
}

Öz

Bu çalışmada, Orta Anadolu'nun güneyinde Konya il sınırları içerisinde yer alan, Gökhöyük Bağları Höyüğünde yapılan kazılarda açığa çıkarılan bir grup pişmiş toprak çanak çömlek ele alınmıştır. Bu grup içinde değerlendirilen parçaların iç kısımlarında bulunan kazımalar ve muhtemelen kap pişirilmeden önce, üretilme aşamasındayken eklenen parmak kalınlığındaki eklentiler bunların diğer seramiklerden ayrı bir grup içerisinde değerlendirilmesine neden olmuştur. Yapılan inceleme ve araştırmalar sonunda çalışmaya konu seramik parçaların pişmiş toprak yayık parçaları olduğu anlaşılmıştır. Yayıklar günümüzde otomatik makinelerin icat edilmesiyle elde yapımı giderek terk edilmeye başlanan sütten yağ elde etmede veya ayran yapımında kullanılan pişmiş toprak ya da ahşap kaplardır. Bu kap formunun en erken örnekleri Orta Anadolu'nun kuzeyinden Yarıkkaya'dan bilinmektedir. 2002 - 2005 yılları arasında Gökhöyük Bağları Höyügü̈nde yapılan kazılarda açığa çıkarılan seramikler arasında 60 adet yayık parçası saptanmıştır. Söz konusu eserlerin koyu yüzlü, çark yapımı kaba mallar olduğu tespit edilmiştir. Anolojik yöntemleri (benzetim sistemi) kullanılarak yapılan incelemeler sonucunda bunların Demir Çă̆g' na tarihlendirilmesi uygun bulunmuştur.

Anahtar Kelimeler: Yayık, Demir Çağı, Konya, Orta Anadolu, süt.

\section{Churn (Yayık): A Preliminary Evaluation on the Production of Milk and Dairy Products in Gökhöyük Bağları Höyüğ̈̈}

\begin{abstract}
In this study, a group of terracotta ceramics unearthed during the excavations at Gökhöyük Bağları Höyüğü, located in the south of Central Anatolia, in the provincial borders of Konya is discussed. Due to the scratches on the inside of some of the pieces evaluated in this group and the finger-thick additions most probably added during the production stage before cooking the pots, these pots were evaluated in a separate group from other ceramics. As a result of the examinations and researches, it was realized that these ceramic pieces were terracotta pieces of churns (Turkish Yaylk). Churns are terracotta containers used to obtain butter from milk, or to make buttermilk; today, however, churnmaking by hand has been abandoned with the inventing of automatic machines. The earliest examples of this form of containers have been known from Yarıkaya in the north of Central
\end{abstract}


Anatolia. 60 pieces of churn chunks were determined among the ceramics unearthed during the excavations at Gökhöyük Bağları Höyüğü between 2002 and 2005. It was observed that those artifacts were dark-surface, wheel-made coarse wares. As a result of the examinations made using anological methods, they were dated to the Iron Age.

Keywords: Churn (Yayık), Iron Age, Konya, Central Anatolia, milk. 


\section{GíRIŞ}

İnsanoğlu yaklaşık olarak MÖ 9.binde bazı hayvanlarla ortak alanlarda yaşamaya başlamış ve böylece ilk evcilleştirmenin adımları (Commensal domestication) atılmıştır (Larson ve Fuller, 2014, p. 115-136). Neolitik Dönemle birlikte MÖ 8. binde etinden ve sütünden yararlanabileceği inek, koyun ve keçi gibi hayvanlar evcilleştirilmeye başlanmıştır (Evershed vd., 2008, p. 1; Trbojević-Vukičević vd., 2011, p. 319-325). MÖ 7. Binyılda ise insanoğlunun süt tüketmeye başladığı bilinmektedir (Schoop, 2017, p. 9). Daha önceleri kesin veriler olmamakla birlikte Kalkolitik Dönemde yaklaşık olarak MÖ 4000 yıllarında bu evcil hayvanlardan karkas et elde etme dişında ikincil ürün (secondary products) olarak değerlendirilen süt ve/veya süt ürünleri de elde edildiği tahmin edilmekteydi (Sherratt, 1981, p. 261). Zamanla yağ asitlerinin uzun yıllar kullanılan kap içinde saklı kalabildiğinin tespit edilmesi ile kaplar üzerinde lipid analizleri yapılmıştır (Evershed, 1993, p. 74-93). Bu yöntemler ile yapılan analizlerden elde edilen sonuçlar süt kullanımının daha erken tarihlerde başladığını ortaya koymuştur ${ }^{1}$. Süt ve süt ürünlerinin Prehistorik Dönemlerde kullanımıyla ilgili daha kapsamlı bir çalışma 2008 yılında Richard P. Evershed ve arkadaşları tarafından yapılmıştır. MÖ 7. ve 5. bin yılları arasına tarihlenen yerleşmelerden alınan 2200 örnek (çömlek veya çömlek parçası) üzerinde yapılan lipid analizleri bize süt tüketiminin MÖ 7. bine kadar gittiğini göstermektedir (Evershed vd, 2008, p. 528-531). Bursa yakınlarında bulunan Barcin Höyükte yapılan kazılarda Neolitik Dönem tabakalarında ele geçen bazı kaplar üzerinden MÖ 6500-6000 yıllarında süt ve süt ürünlerinin insanlar tarafından tüketildiği ileri sürülmüştür (Gerritsen-Özbal, 2011, p. 39-41). Höyükte açığa çıarılan seramikler üzerinde yapılan analiz sonuçları da MÖ 7. binyılda Anadolu'da sütün gıda maddesi olarak tüketildiğini göstermektedir (Özbal vd, 2011, s. 307-317). Konya Ovası Prehistorik Dönem yerleşmelerinden Batı Çatalhöyük'te yapılan kazılarda ele geçen bazı seramikler üzerinde yapılan analiz sonuçları da Konya ve çevresinde süt ve süt ürünlerinin kullanımının MÖ 6. bine kadar uzandığını göstermektedir (Hendy vd., 2018, p. 1-10). Yarıkkaya'da açığa çıkarılan ve Kalkolitik Döneme (yaklaşık olarak MÖ 5500'lü yıllara) tarihlenen pişmiş toprak akıtacaklı kapların (Şekil 1) süt ve süt ürünlerinin işlenmesinde kullanıldığı belirtilmektedir (Sauter vd., 2003, p. 15). Ulf Dietrich Schoop, bu kapların günümüzdeki benzer örnekleriyle karşılaştırarak süt işlenmesi için olası kullanımını 'Anadolu'da Kalkolitik Çağda Süt Ürünleri Üretimi' başlıklı bir çalışmada ayrıntılı olarak anlatmaktadır (Schoop, 1998, p. 26-32). Ancak sütten ikincil üretim olarak yağ gibi ürünlerin elde edildiğine dair kesin sonuçlar Yarıkkaya'da ele geçen ve 'Yayık' olarak değerlendirilen kaplar üzerinde 2003 yılında yapılan analizlerden elde edilmiştir (Sauter vd., 2003, p. 15-21). Çamlıbel Tarlası mevkiinde yapılan son dönem kazılarında elde edilen veriler Kalkolitik Dönemde yağ üretilmiş olabileceği tezini desteklemektedir (Schoop, 2017, p. 1-19). Süt ve süt ürünlerinin işlenmesinde kullanıldığı anlaşılan bu kap yağ küpü olarak adlandırılmıştır (Schoop, 2017, p. 8). Schoop, Tunç Çağlarında yaygın olarak kullanılan süzgeçli kapların sütün süzülmesinde kullanılmış olabileceğini ileri sürmektedir (Schoop, 1998, p. 26-32). Bununla birlikte Tunç Çağı'na tarihlenen yayık örnekleri genelde batı Anadolu'da Troya, Kaklık Mevkii, Karataş Semayük (Şekil 2) gibi yerleşmelerde (Cultraro, 2013, p. 157-189) ve Ege'de Yunanistan'ın kuzeyinde Selanik'e çok yakın bir yarımada olan (Torone/ Chalkidike)

\footnotetext{
${ }^{1}$ Andrew Sherratt 1981 yılında yaptığı çalışmayla süt üretiminin (sütçülüğün) ikincil ürün devriminin bir parçası olduğunu ve başlangıçtaki Avrupa ve Akdeniz Neolitik dönemlerinin bir parçası olmadığını belirtmişti. Ancak daha sonraki çalışmalar en azından belirli süt ürünlerinin erken dönemlerden beri mevcut olduğunu göstermiştir (Evershed vd., 2008,; Itan vd.,, 2009,; Salque vd., 2013).
}

SEFAD, 2020; (43): 325-344 
(Şekil 3) Halkidiki'de ele geçmiştir² (Morris, 2013, p. 70-79). Bunların dişında Gre Vrike Höyük'te Erken Tunç Çağı III'e (ETÇ III) tarihlenen tabakada bulunan bir kap formunun (Şekil 4) Yarıkkaya'daki kaplara benzer bir yayık form özelliği gösteriyor olması, Tunç Çağı'nda Anadolu'nun güneyinde de pişmiş toprak yayık kapların kullanılmış olabileceğini akla getirmektedir (Ökse, 2002, s. 267). Ancak bu kap üzerinde ayrıntılı çalışmalar bulunmadığından kabın yayık olarak kullanılmış olduğuna dair kesin veriler bulunmamaktadır. Bununla birlikte Anadolu dışında MÖ 2500'lerde Basra Körfezi'nin uç kısmında yer alan ve bir Sümer yerleşimi olan Tell Ubaid'deki Ninhursag Tapınağı'nın frizlerinde süt ve süt ürünlerinin işlenmesine ve pişmiş toprak yayık kapların kullanımına dair (Şekil 5) ilk görsel kanıtlar görülmektedir (McCormick, 2012, p. 102; Powroznik, 2008, p. 226). Asur Ticaret Kolonileri Çağı'nda sütün kullanımı ile ilgili Kültepe-Kaneş'te bulunan tabletler bu konuda bilgi vermemektedir. Bununla birlikte kazılarda bulunan çok sayıda hayvan kemiği (inek ve koyun gibi) üzerine çalışan Levent Atıc1, süt ve süt ürünlerinin yerel ölçekte biliniyor olma ihtimalini göz önünde bulundurmaktadır (Atıcı, 2014, p. 233-252). Hitit Dönemi'nde ise yayık kullanıldığına dair arkeolojik veriler bulunmaktadır. MÖ 2. bine tarihlenen İnandık Vazosu üzerinde anlatılan sahnelerden en altta dördüncü frizin başında yayık kap betimlenmektedir (Özgüç, 1988, s. 20). Bu frizde uzun elbiseli olarak betimlenen bir kadının iki eli ile tuttuğu yuvarlak başlı bir alet (sopa ?) ile önündeki vazo olarak tanımlanmış yayık kabının içini karıştırdığı (Şekil 6) görülmektedir (Özgüç, 1988, s. 175, Fig. 65, Lev. 44). Demir Çağları'nda (MÖ 1200 ile 330 yılları arasında) ise sütün işlenerek süt ürünlerinin üretildiğine dair daha kesin veriler ortaya konmuştur. Son yıllarda kazıları yapılan ve Demir Çağı tabakaları ayrıntılı olarak incelenen Kaman-Kalehöyük (Şekil 7) ve $\mathrm{Kuşakl1}^{3}$ (Şekil 8) gibi yerleşmelerde açığa çıkarılan pişmiş toprak yayıklar Demir Çağı'nda sütten yağ üretildiğini göstermektedir (Powroznik, 2008, p. 225-231). Halen kazıları devam eden Maydos Kilisetepe'de 2018 kazı sezonunda Geç Geometrik/ Arkaik Döneme ait tabakada ele geçen ve tereyağı yapımında kullanıldığı düşünülen bir yayık kabının (Şekil 9) bulunduğu bildirilmiştir4. Maydos Kilisetepe'de bulunan bu kabın tanıtımı kazı başkanı tarafından görsel basında yapılmıştır. Gökhöyük Bağları Höyüğü'nde Demir Çağı tabakalarında $^{5}$ açığa çıkarılan pişmiş toprak yayık parçalarıda Demir Çağı'nda Orta Anadolu'nun güneyinde süt ve süt ürünlerinin işlendiğine dair yeni kanttlar ortaya koymaktadır. Çeşme Müzesi'nde bulunan bir yayık amphora ise Roma veya Geç Roma Dönemi'nde de yayığın kullanımının devam ettiğini göstermektedir (Okan, 2013, s. 101-108).

\footnotetext{
${ }_{2}^{2}$ Batı Anadolu' da Tunç Çağında yayık olarak kullanıldığı tahmin edilen bu kapların tamamı yatay formludur. Bunlar Barrel-Shaped Vessels olarak adlandırılmışlardır.

${ }^{3}$ Bunun dışında Sivas Arkeoloji Müzesi teşhir salonunda sergilenen ve Kuşaklı kazı buluntuları envanterine kayıtlı bir yayık kap (küp) bu dönemde yayık kullanıldığına dair önemli veriler sunmaktadır. Bkz. (Şekil 8)

${ }^{4}$ Maydos Kilisetepe kazı başkanı sayın Doç.Dr. Göksel SAZCI kabın Geç Geometrik/Arkaik Döneme ait tabakada ele geçtiğini bildirmiştir. Değerli bilgileri ve yayık kabının fotoğraflarını benimle paylaşan, fotoğrafları bu çalışmada kullanmama izin veren Doç.Dr. Göksel SAZCI'ya teşekkür ederim. Ayrıca SAZCI yapılan görüşmede kap içerisinden bazı örneklerin analiz çalışmaları için alındığını ancak henüz bu çalışmaların tamamlanamadığını bildirmiştir.

${ }^{5}$ Tarafımdan 2019 yılında Selçuk Üniversitesi Sosyal Bilimler Enstitüsü’nde “Gökhöyük Bağları Höyüğü Demir Çağı Seramiğii" konulu doktora tezi tamamlanmıştır. Bu çalışma kapsamında höyükte ele geçen koyu yüzlü seramiklerin analojik yöntemlerle Demir Çağı seramikleri olduğu tespit edilmiştir. Bu seramikler 1şığında aynı tabakada bulunan yayık kap parçalarının da Demir Çağı'na tarihlenmesi yanlış olmayacaktır. Burada incelenen seramikler, höyükte Demir Çağı seramikler ile birlikte bulunan ancak farklı yapılarından dolayı doktora çalışmasına dahil edilmeyen çoğunluğunu amorf seramiklerin oluşturduğu parçalarıdır.
} 


\section{TOPRAK YAYIKLAR VE KULLANIMI}

Yayık kelimesinin tam olarak karşılığı, tereyağı çıkarmak için sütün, yoğurdun veya kremanın içinde çalkalandığı kap veya makine olarak belirtilmiştir ${ }^{6}$ (Ayverdi, 2011, s. 3390). Bu kap ve/veya makine ile yapılan eyleme de yayıklama denir7. Günümüzde yayıkların gelişen teknolojiyle birlikte elektrikli makinelerden yapılan örnekleri daha yaygın olarak kullanılmaktadır (Sauner, 2018, p. 13). Bununla birlikte az da olsa eski gelenek devam ettirilmekte pişmiş topraktan ve ahşaptan yapılmış yayıkların kullanımı da halen devam etmektedir (Karpuz ve Ürekli, 2011, s. 169-177). Yaygin olarak topraktan yayıklar tercih edildiği görülmektedir. Frances James'e göre yayık yapımı için pişmiş toprak kabın tercih edilmesi, gözenekli yapısından dolayı sütün serin tutması ile açıklanmaktadır. Yayık içine konulan karışımdaki tereyağı partiküllerinin granülasyonunun bu sayede daha hızlı olacağı, dolayısıyla daha az çabayla daha çabuk tereyağı elde edilebileceği ileri sürülmektedir (James, 1975, p. 37). Yapılan araştırmalara göre pişmiş toprak yayıklar genel olarak yatay ve dikey olmak üzere iki farklı form altında değerlendirilebilmektedir. Bunlardan ilki tanımlanmasından da anlaşılacağı gibi, yatay bir gövdeye sahiptir. Bunlar arkeolojik literatürde Barrel-Shaped Vessels olarak adlandırllırlar (Cultraro, 2013, p. 157-189; Morris, 2013, p. 70-79; Morris, 2014, p. 205-222). Bu yatay gövdenin ortasında ise silindirik bir boyun (Şekil. 10) bulunmaktadır. Gövdenin her iki kenarı da kapalıdır. Bazı örneklerde bunları iki ucunda kabı bir yere asmak ve/veya sallamak için ip bağlama yerleri olduğu görülmektedir (Takaoğlu, 2006, s. 44; Cultraro, 2013, p. 157-189; Morris, 2013, p. 70-79; Morris, 2014, p. 205222). Bu formun Anadolu'da ve Anadolu dişında bulunan en erken örnekleri Kalkolitik Döneme tarihlenir. Anadolu dişında bilinen örnekler Levant bölgesi, Filistin'de açığa çıkarılmıştır (Takaoğlu, 2006, s. 23-44; Morris, 2014, p. 205-222). Bu formun Kalkolitik Döneme tarihlenen en erken Anadolu örneği ise Amasya Arkeoloji Müzesi teşhir salonunda bulunmaktadır(Şekil 11). Tunç Çağı yatay formlu yayık örnekleri ise Batı Anadolu yapılan kazılarda ve Yunanistan'ın (Torone, Chalkidike) Halkidiki' de yapılan kazılarda ele geçmiştir (Cultraro, 2013, p. 157-189; Morris, 2013, p. 70-79; Morris, 2014, p. 205-222; Takaoğlu, 2006, p. 23-44). Çeşme Müzesi envanterine kayıtlı bir adet Roma Dönemi'ne tarihlenen yatay yayık ise bu formun bilinen en geç Roma Dönemi örneğidir (Okan, 2013, s. 101-108). Bu verilerden yola çıkarak günümüzde kısmen de olsa kullanımı devam eden yatay formlu yayık kapların Kalkolitik Dönem'den Roma Dönemi'ne kadar kullanıldığını söylemek yanlış olmayacaktır.

İkinci yayık formu ise dikey yayıklardır. Bunlar özel olarak küp formunda yapılmış kaplardır. Dikey formlu yayıkların Kalkolitik Döneme tarihlenen en erken örnekleri Yarıkkaya'da yapılan kazılarda ele geçmiştir (Schoop, 1998, p. 26-35). Erken örneklerde kabın kaideye yakın kısmında içindeki sıvıyı boşaltmak için tahliye delikleri bulunur (Şekil 1). Daha geç döneme tarihlenen örneklerde kabın boyun kısmında veya omuz kısmında iki adet kulp bulunur. Özellikle Demir Çağı (Kaman-Kalehöyük ve Kuşaklı) örneklerinde ise kabın içerisindeki karışımı kontrol edebilmek için omuz üzerinde kulbun yanında veya altında bir yuvarlak delik bulunur (Şekil 7-8). Bu delik Demir Çağı örnekleri için karakteristiktir.

\footnotetext{
${ }_{6}$ Yayık kelimesinin anlamı için bkz. (http://www.tdk.gov.tr/index.php?option=com_bts\&arama=kelime\&guid=TDK.GTS.5d7cd805da4d27.71545492) 7 Yayıklama, tereyağı elde etmek amacıyla süt, yoğurt veya kremadaki yağın belirli koşullar altında serumdan ayrılmasını sağlamak için yayık denilen özel ekipmanlarda karıştırılması işlemi olarak tanımlanmıştır. Bkz. Milli Eğitim Bakanlığı Gıda Teknolojisi Kitabı (http://megep.meb.gov.tr/mte_program_modul/moduller_pdf/Tereya\%C4\%9F\%C4\%B1.pdf).erişim
} tarihi.19.11.2019) 
Pişmiş toprak yayıkların erken dönem kullanım yöntemi hakkında ilk görsel veriler yukarıda da bahsettiğimiz gibi Tell Ubaid'deki Ninhursag Tapınağı'nın frizlerinden gelmektedir (McCormick, 2012, p. 102; Powroznik, 2008, p. 226). Ninhursag Tapınağı'ndaki bu frizler (Şekil 3), süt sağımı ile beraber yayığın da neredeyse günümüzdeki şekilde, bu tarihte kullanıldığını gösteren önemli bir görseldir (Powroznik, 2008, p. 226). Sütün sağılmasından başlayarak pişmiş toprak yayık kaplarda yayılmasına kadarki süreç bu frizlerde anlatılmaktadır. Bu konu hakkında bir başka görsel veri ise İnandık Vazosu üzerindeki betimlemedir8. Yayıkların kullanım yöntemleri günümüzde bölgesel farklılıklar gösterse de genel olarak bir birine benzemektedir (Karpuz ve Ürekli, 2011, s. 169-177). Pişmiş toprak yayık ile sütten tereyağı yapılabilmesi için karışımın bazı aşamalardan geçmesi gerektiği bildirilmektedir. Bu süreçte öncelikle sütün fermante olabilmesi için süt az miktarda yoğurt ile karıştırılır. Bu karışıma aynı zamanda su da ilave edilerek karışım iyice seyreltilir. Burada çömleğin ağız kısmı ve çömlekte özellikle yapılmış bulunan açıklık (delik) iyice kapatılmalıdır. Ancak yayıklama işleminin başlaması ile sütün fermantasyonu gerçekleşirken açığa çıkacak gazın boşaltılması veya zaman zaman yağın olup olmadığının kontrolünün yapılabilmesi için bu deliğin ara ara açlıp kapanabilecek şekilde kapanması gerekmektedir (Schoop, 1998, p. 29; Karpuz ve Ürekli, 2011, s. 174). Bu aşamalardan sonra hazırlanan karışımın konulduğu kap yere doğru uzatılarak sallanarak karışım yayıklanır9. Farklı yörelerde farklı uygulamalar ve yayık örnekleri olduğu bilinse de genel olarak uygulanan teknik yukarıda anlatıldığı gibidir. Bu yayıklama işlemi ile sıvı içindeki yağ taneleri birbirleriyle birleşir ve sıvı halde kalan serum yağdan ayrılır. Bu eylemin bitmesinin ardından kapta biriken yağ taneleri sıkıştırılarak yıkanır ve saf yayık yağı elde edilmiş olunur (Şenel vd., 2010, s. 267-274).

\section{GÖKHÖYÜK BAĞLARI HÖYÜĞÜ}

Gökhöyük Bağları Höyügü (GBH- olarak kısaltması da kullanılacaktır) Konya ili Seydişehir ilçesi Gökhöyük mahallesi Bağlar mevkiinde bulunmaktadır. Höyük yaklaşık olarak 29 hektarlık bir alana oturmaktadır. Höyüğün Ova tabanından yüksekliği ise 11 metredir. Höyükte 2002 - 2005 yılları arasında yapılan kazılarda çok sayıda pişmiş toprak eser ortaya çıkarılmıştır. Kazı raporlarında belirtilen, kısmen sağlam kalmış mimari kalıntılar, ele geçen farklı buluntular yanında pişmiş toprak seramiklerden yola çıkarak tarafımızdan höyüğün tabakalanma önerisi yapılmıştır (Gündüz, 2019a, s. 68). Bu verilere göre höyükte en üstten aşağıya Roma-Helenistik dönemden başlayarak Demir Çağı, Tunç Çağı, Kalkolitik ve en altta Neolitik Dönem kültürlerinin yaşandığı anlaşılmıştır (Gündüz, 2019d, s. 41-52). Höyüğün en üst katmanı zamanla oluşan doğal erozyon yanında höyügün geç dönemlerde (İslami Dönem) mezarlık alanı olarak kullanılmasından dolayı tahrip edilmiştir. Bunun yanında höyügüun günümüzde olduğu gibi uzun zamandır tarım arazisi

\footnotetext{
${ }^{8}$ Bu sahnede görülen kişi günümüzde 'Gümbür Yayık da olarak bilinir' ahşaptan yapılan ve Bişşek adı verilen bir sopayla üstten vurularak yapılan bir yayık çeşidiyle yapma eyleminde kullanılan malzemelere benzerliğinden bu sahnenin yayıklama sahnesi olabileceği akla gelmektedir. Bira ve Şarap gibi içeceklerin saklama kaplarında karıştırılma ihtimali düşük olduğundan (bunların dinlenip posalarının dibe çökmesi daha elzemdir) bu kapta süt ve/veya süt ürünlerinden bir ürünün olma ihtimali akla gelmektedir. Yayık çeşitleri ve kullanımları ile ilgili ayrıntılı bilgi için bkz. Karpuz ve Ürekli, 2011, s. 169-177.

9 Yayıklama eyleminin bu şekilde yapıldığını gösteren ilk görsel veriler MÖ 2500'e tarihlenen, Güney Irak'ta bulunan Tell Al-'Ubaid, Ninhursag Tapınağında frizlerinde görülmektedir. Bu frizlerde süt sağımı ve sütün işlenmesi görsel olarak anlatılmıştır. Günümüzde bu işlem yapılırken hem daha iyi sallanması hem de sallama esnasında sert zemine çarpıp kırılmasının engellenmesi için kabın altına yumuşak yastık minder benzeri koruyucular konulmaktadir.
} 
olarak kullanılmasından dolayı Helenistik-Roma Dönemleri'nin bulunduğu tahmin edilen tabakanın ağır tahribat gördüğü anlaşılmaktadır. Bu dönemler yalnız seramik buluntular ile tespit edilebilmekte olup bunun dışında herhangi bir mimari buluntu ile karşılaşılmamıştır. Yüzey toprağı ile karışık Hellenistk-Roma Dönemi altında Demir Çağı kültür tabakası bulunmaktadır. Derin kazılan İslami Dönem mezarları tarafından ağır tahribata uğramış bu dönem kısmen sağlam kalabilmiş taş duvar temelli mimari yapı ile temsil edilir (Gündüz, 2019b, s. 204-222). Demir Çağı kültürleri arasında erken, orta ve geç safha mimari olarak ayırt edilememekle birlikte, höyükte seramikler üzerinden Demir Çağı'nın her üç safhasının da yaşandığı açıkça anlaşılmaktadır. Gökhöyük Bağları Höyüğü Demir Çağı Seramikleri başlığ 1 altında 2019 yılında tamamlanan doktora tezi kapsamında yapılan çeşitli yayınlarda kap formları yapısal özellikleri ve yüzey işlemelerine göre dönemlere ayrılmıştır ${ }^{10}$ (Gündüz, 2019a; Gündüz, 2019b, s. 204-222; Gündüz, 2019c, s. 465-484).

\section{GBH YAYIK BULUNTULARI}

Çalışmaya konu seramikler Höyüğün Demir Çağı'na tarihlendirilen katmanlarında, bu bölge için karakteristik Demir Çağı seramiği olarak tanımlanan koyu renkli (çoğunlukla gri) mat yüzeyli, kaba seramikler ile birlikte bulunmuştur. Bunlar, iç kısımları özellikle kazınmış, içlerinde eklentileri olan (Şekil 12), diğer seramiklere göre farklı yapısal özelliklere sahip pişmiş toprak parçalardır ${ }^{11}$. Tarafımızdan yapılan çalışmalar sonucunda bunların yayık olarak adlandırılan kaplara ait parçalar oldukları anlaşılıışır. Yayık parçalarının höyük topografyasına göre, höyügün güney kısmında kalan 16-17-18- D-F-G olarak adlandırılan alanlarda Demir Çağı seramikleri ile aynı seviyeden çıkarıldığı kazı raporlarından anlaşılmıştır. Ayrıca bu kapların benzer örnekleri Kaman-Kalehöyük yerleşmesinde C14 sonuçları ile kesin tarihlemeleri yapılmış Demir Çağı tabakalarında ele geçmiştir (Matsumura, 2005,; Powroznik, 2008, p. 225-231). Demir Çağı' na tarihlenen seramik buluntuları arasında tespit edilen toplamda 60 adet parça bu çalışmada değerlendirilmiştir. Bu parçalar arasında maalesef bütün ve/veya bütünlenebilecek bir yayık kabı bulunmamaktadır. İncelenen buluntular arasında iki adet ağız, bir kulp ve dört kaide bulunmaktadır (Şekil 13-14). Bunların dışında kalan parçaların tamamı (amorf) gövde parçalarından oluşmaktadır. GBH yayık buluntuları üzerinde herhangi bir bilimsel analiz yapılmamış olup örneklerin değerlendirilmeleri analojik yöntemler kullanılarak yapılmıştır.

\section{Yayıkların Formsal Özellikleri}

GBH yayık kap parçaları form olarak ele alındığında, bunların genel olarak dikey yayık kaplarına ait parçalar olduğu anlaşılmaktadır. Yatay forma ait bir yayık parçası henüz tespit edilememiştir. İncelenen iki adet ağız kenarı örneğinden bu kapların yaklaşık $12-15 \mathrm{~cm}$ çapında ağız genişliğine sahip, dar, boyunlu, dışa kalınlaştırılmış dudaklı bir forma sahip oldukları anlaşılmıştır (Şekil 13). Kabın boyundan omuza geçiş keskin değildir. Omuz kısmına geçişte muhtemelen karşılıklı iki adet dikey kulpu bulunur ${ }^{12}$. Bu kapların erken örnekleri olarak değerlendirilen Yarıkkaya ve Çamlıbel Tarlası örneklerinde kulp görülmez. Demir Çağı örneklerinde kulbun bazı örneklerde altında bazı örneklerde yanında, özenli bir

\footnotetext{
${ }^{10}$ Demir Çağı seramiklerinin dönemsel ayrımı, Kaman-Kalehöyük, Gordion, Boğazköy, Kınık Höyük gibi kısmen C14 tarihlemeleri yapılan yerleşmeler referans alınarak, analojik yöntemler ile yapılmıştır.

${ }^{11}$ Bu seramikler farklı yapısal özelliklerinden dolayı doktora kapsamı dışında tutulmuştur.

${ }^{12}$ Günümüz yayık kaplarında kulpların bazı örneklerde dikey bazı örneklerde ise yatay ve ya çapraz şekilde tam olarak omuz ile boyun kısmına geçişe konmuş olduğu görülmektedir. (Resim 15)
}

SEFAD, 2020; (43): 325-344 
şekilde ağız formu verilmiş, bir delik bulunmaktadır ${ }^{13}$. Ağızın bu şekilde özenli yapılması yalnız GHB örneklerinde değil Kaman-Kalehöyük ve Kuşaklı örneklerinde (Şekil 7-8, 12.) de belirgindir (Powroznik, 2008, p. 229-230). Yayıkların omuzdan karına doğru genişleyen küresel bir gövdeye sahip kaplar olduğu anlaşılmaktadır. Geniş gövde kaideye doğru daralır ve düz bir kaide üzerine (Şekil 14) oturur. Tahsin Özgüç İnandık vazosu üzerinde betimlenen yayık kabını çift kulplu, yumurta gövdeli ve uzun boyunlu olarak tanımlamıştır (Özgüç, 1988, s. 19-20). Klaus Powroznik ise Kaman-Kalehöyük yayık kaplarını dar boyunlu şişkin gövdeli karından kaideye doğru daralan formlu olarak tanımlamıştır. Hatta yayıkların şişkin gövdelerinden dolayı soğan şekline yakın bir formda olduklarını vurgular (Powroznik, 2008, p. 225). Böylesi geniş küresel bir gövdeye göre oldukça küçük çaplı yapılan düz kaide dikkat çekicidir ${ }^{14}$. Olasılıkla bu kap kendi kaidesi üzerinde durmakta güçlük çekiyor olmalıydı. Kaman-Kalehöyük Demir Çağı tabakalarında ele geçen yayık kapları da benzer kaide formuna sahiptir (Powroznik, 2008, p. 229). İnandık Vazosu üzerinde betimlenen yayık kabında kendi kaide üzerinde değil kabın oturabileceği bir ayak veya kaide üzerine oturduğu görülmektedir (Özgüç, 1988, s. 175 Fig. 65, Lev.44). Bu bilgilerden hareketle Kaman-Kalehöyük ve Kuşaklı örneklerini de referans alarak Gökhöyük Bağları Höyüğü yayıklarının yaklaşık olarak $70 \mathrm{~cm}$ boylarında15, karın kısmı $45-50 \mathrm{~cm}$ genişliğinde dişa çekik ağız kenarlı, dar boyunlu, şişkin karınlı, düz kaideli oldukları anlaşılmaktadır. Günümüz dikey formlu yayık kap boyutlarının da yaklaşık olarak aynı özellik ve ölçüye sahip olduğu örneklerden anlaşılmaktadır (Şekil 15).

\section{Yayıkların Yapısal Özellikleri}

GBH yayık buluntuları yüzey özellikleri ve kil hamurları dikkate alınarak incelendiğinde, kapların genelinin koyu renkli mat yüzeyli olduğu görülmektedir. Orta Anadolu'nun güneyi ve GBH Demir Çağı seramikleri için karakteristik olarak kabul edilen gri yüzey yayıklar için de söz konusudur. İncelenen parçalar arasında devetüyü veya açık kahverengiye yakın bir renge sahip birkaç örnek bulunmaktadır. Bunların dışında kalan parçaların tamamının gri renkte yüzeye sahip olduğu tespit edilmiştir. İncelenen örneklerden kapların dış yüzeylerinin astarlı oldukları anlaşılmıştır. Yayık parçalarının hiç birinde açkı uygulaması görülmezken genelde düzleştirilmiş mat yüzeyli oldukları anlaşılmaktadır. Bu parçaların hamurunda taşçı, kireç, kum ve az miktarda gümüş mika bulunmaktadır. Parçalarda kaba taşçık veya organik katkı bulunmaz. Büyük çoğunluğu sert ve gözenekli yapıdadır. Ancak kısmen sıkı dokulu yapıda olanlar da mevcuttur. GBH Demir Çağı çömleklerinin büyük bir kısmında görülen belirgin seviyedeki kireç katkı bazı yayık parçalarında da görülür (Şekil 16). Muhtemelen kabın işlevsel özelliğinden dolayı bazı

\footnotetext{
${ }_{13}$ Bu dönem yayık kaplarının en belirgin özelliklerinden biride kulbun hemen sağında veya solunda çalkalama sırasında içeride oluşan basıncın dışarı atılması için ağız görevi gören bir küçük deliğin olmasıdır. Ayrıntılı bilgi için bkz. Powroznik, 2008, p. 225-231. Bu delik yayığın kıvamının tutup tutmadığının kontrolünü sağlar ayrıca Yayıklama işlemi bittikten sonra, yayıkaltı adı verilen sıvının tamamen boşaltılması için kullanılıyor olmalıdır. Bu deliklerin erken örnekleri ile karşılaştırması yapıldı̆̆ında Schoop'un yayıkların erken örnekleri olarak bilim dünyasına tanıttığı Yarıkkaya'da ele geçen Kalkolitik Dönem kapları akla gelmektedir. Ancak Kalkolitik Dönem örnekleride bulunan delikler kulpun yanında veya altında değil kabın kaidesine yakın bir yerde bulunmaktadır. Ayrıntılı bilgi için bkz. Sauter vd. 2003, p., 15-21.

${ }_{14}$ S.Ü Edebiyat Fakültesi girişinde bulunan iki adet günümüz yayık kabı bunlar için özellikle yapılan metal ayaklar üzerinde durmaktadır. Bu örnekleri incelediğimizde, günümüz yayıklarının da dar bir kaideye sahip olduğu ve kendi başlarına ayakta durma kabiliyetlerinin olmadığı görülmektedir. Bu da yayıkların MÖ 2500'e tarihlenen Ninhursag Tapınağının frizlerinde olduğu gibi yere doğru uzatılarak yada belli bir yere yerleştirilerek kullanılmış alabileceğini akla getirmiştir.

${ }^{15}$ Maydos Kilisetepe kazısında ele geçen yayık da $72 \mathrm{~cm}$ boyunda ve $50 \mathrm{~cm}$ genişliğindedir.
} 
örneklerin iç kısımlarının da kendi kil renginden daha koyu renkte yoğun kıvamlı bir maddeyle sıvandığı görülmektedir. Büyük olasılıkla bu şekilde yoğun bir astar ile yapılan astarlama (sıvama) uygulaması yayık örneklerinin sıvı ve/veya hava giriş çıkışını engellemek için yapılmış olmalıdır ${ }^{16}$. Üretim tekniği açısından değerlendirildiğinde örneklerin tamamının çarkta üretilmiş olup özensiz kaba mallar olduğu anlaşılmaktadır. Bu kapları diğer çömleklerden ayıran bir başka karakteristik özellik ise iç kısımlarında neredeyse kabın tamamında karışık şekilde yatay dikey yönlü kazımalar (Şekil 16) bulunmasıdır. Kapların içindeki bu kazımanın benzer kullanımı Demir Çağı KamanKalehöyük örneklerinde de görülür (Powroznik, 2008, p. 229). Tunç Çağı'na tarihlenen (Chalkidike) Halkidiki'de bulunan yatay yayık parçalarında da benzer kazıma görülmektedir (Morris, 2013, p. 71). Bu örneklerin tamamının benzer şekilde kap yapımı tamamlanmadan (kap henüz pişirilmemiş halde deri sertliğinde iken) özellikle kazındığı anlaşılmaktadır. GBH yayık kap parçalarının iç kısmına, bu kazımalara ilaveten kabın kendi kilinden eklentiler konmuştur. Ele geçen örneklerden kabın iç kısmına kaideden ağız seviyesine kadar, başparmağı kalınlığında kil ile (Şekil 12-14, 17) karşılıklı yan yana setler yapıldığı anlaşılmaktadır ${ }^{17}$. Kabın gövdesine yapılan bu eklentiler yanında kabın kaidesinin iç kısmına, yayığın dibine, yerleştirilmiş dikey yumrular (Şekil 14) da bulunmaktadır ${ }^{18}$. Bu eklentilerin tamamı kabın ilk yapım aşaması sırasında yapılmış olmalıdır. Bu durumda da bu tür kapların yapım aşamasında özellikle belirli bir iş ve/veya eylem için üretilmiş oldukları anlaşılmaktadır.

\section{Yayıkların Tarihlendirilmesi}

Gökhöyük Bağları Höyüğü yayık kap parçalarının C14 tarihlendirme yöntemi ile kesin tarihlendirmeleri yapılmamıştır. C14 sonuçları ile kesin tarihlemeleri yapılmış KamanKalehöyük yerleşmesi Demir Çağı tabakalarında ele geçen yayık buluntuları, GBH yayık parçalarının tarihlenmesinde yol gösterici olmuştur. GBH buluntuları Kaman-Kalehöyük buluntuları dışında Kuşaklı yerleşmesinde ve Maydos Kilisetepe kazısında ele geçen yayık olarak tanımlanan kaplar ile de kıyaslanmıştır. Bununla birlikte GBH kazılarında Demir Çağı olarak tanımlanan tabakada ele geçen koyu yüzlü seramiklerin Demir Çağı seramikleri olduğu analojik yöntemlerle tarafımızdan teyit edilmiştir ${ }^{19}$. Bu bağlamda höyükte Demir Çağı seramikleri ile aynı tabakada bulunan yayık kap parçalarının da Demir Çă̆ı'na tarihlenmesi yanlış olmayacaktır.

\footnotetext{
$\overline{{ }^{16} \text { Kabın hava }}$ geçirgenliği ne kadar az olursa içindeki karışım daha uzun süre soğuk kalır ve yağ partükülleri daha hizlı oluşur.

17 Bunun sebebinin yayığın kullanılırken sağa sola hareketinde içindeki sütün bu set ve kanallara çarparak bu sayede tereyağı partiküllerinin granülasyonunun hızlanması sonucunda, daha çabuk tereyağı elde edilmesi olmalıdır.

18 Hem Kaman-Kalehöyük örneklerinin, hem de Kuşaklı yayık kap örneğinin iç kısmında benzer eklenti bulunmaktadır. Ayrıntılı bilgi için bkz. Powroznik, 2008, p. 229.

${ }_{19}$ Gökhöyük Bağları Höyüğü Demir Çağı seramikleri hakkında 2019 yılında Selçuk Üniversitesi Sosyal Bilimler Enstitüsü'nde tamamladığım "Gökhöyük Bağları Höyüğü Demir Çağı Seramiği” konulu doktora tezinde ayrıntılı bilgi sunulmuştur. Burada incelenen eserler, höyükte Demir Çağı seramikler ile birlikte bulunan ancak farklı yapılarından dolayı doktora çalışmasına dahil edilmeyen çoğunluğunu amorf seramiklerin oluşturduğu parçalarıdır.
}

SEFAD, 2020; (43): 325-344 


\section{SONUÇ}

Arkeolojik kazılarda ele geçen pişmiş toprak kaplar üzerinde yapılan analizlerle İnsanoğlunun süt ve süt ürünleri tüketimine Neolitik Dönem'de başladığı ortaya konmuştur. Anadolu'da birçok Prehistorik yerleşmeden (Barcin Höyük, Çatalhöyük) alınan örnekler üzerine yapılan analiz sonuçları da bunu desteklemektedir. Kalkolitik Dönem'le birlikte sütten tereyağı gibi ikincil ürünler elde edildiği ele geçen pişmiş toprak eserlerden (Yarıkkaya, Çamlıbel Tarlası) anlaşılmaktadır. Kaman-Kalehöyük kazılarında tespit edilen bir grup eser, bu eylem için günümüzde kullanıldığı gibi benzer özelliklere sahip pişmiş toprak Yayık aplarının ilk kez Demir Çağı'nda üretildiğini ortaya çıkarmıştır. GBH kazılarında açığa çıkarılan seramiklerin bir kısmı tarafımızdan incelenmiştir. Farklı yapısal özelliklerinden dolayı ayrılan bir grup seramik parçasının yapılan araştırmalar sonucu yayık kaplarına ait parçalar olduğu tespit edilmiştir. Bu çalışma ile bu kap tiplerinin önerilen işlevi güncel örneklerle açıklanmış ve bunların en erken örnekleri ile Demir Çağı'na tarihlenen diğer yerleşmelerde ele geçen örnekler karşılaştırılmıştır. İncelenen GBH buluntularının günümüzde az da olsa kullanımı devam eden pişmiş yayık kaplarının Demir Çă̆ı'na tarihlenen erken örnekleri olduğu anlaşılmıştır.

Sonuç olarak Gökhöyük Bağları Höyüğü yayık kap buluntuları Anadolu'nun güneyinde Demir Çağı'nda süt ve süt ürünlerinin üretimini gösteren ilk örnekler olması bakımından büyük önem arz etmektedir. Süt ürünlerinin işlenmesinde kullanılan tarafımızdan Demir Çağı'na tarihlenen GBH yayık buluntuları henüz yapım aşamasında iç kısımlarının kazınması ve içlerine kil eklentilerin konması ile seramikler içinde ayrı bir grup olarak değerlendirilmiştir. Diğer kaplardan farklı olarak özellikle bu formlarda bir kabın üretilmesi ise GBH sakinlerinin süt işlemesi konusunda uzmanlaştığını düşündürmektedir. Süt ürünlerinin işlenmesi için tesadüfi herhangi bir kap kullanılmamış aksine bu iş için özenle hazırlanan kaplar üretilmiştir. $\mathrm{Bu}$ tecrübe de uzun zamandır aktarıla gelen deneyimlerin ve kültürel birikimin sonucu olmalıdır. Buda GBH Demir Çağı sakinlerinin erken ataları ile bağlarının kopuk olmadığını, Geç Tunç Çağı ile Demir Çağı arasında bir devamlılı̆̆ın söz konusu olduğunu düşündürmektedir. Buradan yola çıkarak da, MÖ 1200'lerde başlayan kavimler göçü ile Anadolu'nun tamamen yerle bir edildiği, kültürel sürecin kesintiye uğradığı ve Anadolu'nun Karanlık Çağa girdiği tezinin en azından Orta Anadolu'nun güneyinde bulunan Gökhöyük Bağları Höyüğü yerleşmesi için geçerli olmadığını söylemek yanlış olmayacaktır. Bununla birlikte, incelediğimiz yayık kaplarından yola çıkarak Demir Çağı'nda GBH sakinlerinin refah seviyesi yüksek bir topluluk oldukları düşünülmektedir. Çünkü iddia ettiğimiz gibi bu kaplar ile süt veya süt ürünlerinden yağ üretilmişse bunun elde edilmesi için fazlaca süte ihtiyaç vardır. Bu da hali hazırda çok fazla sağılır hayvanın olmasını gerektirir. Çünkü bu günkü şartlarda bir (1) kilo tereyağ elde etmek için ortalama 16 - 18 litre süte ihtiyaç vardır. Günümüzde normal şartlarda bakılan (özel bir cins olmayan) bir koyundan ve ya keçiden yaklaşık olarak bir (1) kilo süt, bir inekten ise 5 ile 8 kilo arasında süt elde edilmektedir. Benjamin S. Arbuckle'nin Bronz Çağ ve Demir Çağı hayvan popülasyonu hakkında bilgiler verdiği The Rise of Cattle Cultures in Bronze Age Anatolia adlı makalesi Demir Çağı'nda koyun ve keçi ağırlıklı hayvanların daha çok bulunduğunu ineklerin ise \%22 lik bir orana sahip olduğunu göstermektedir. $\mathrm{Bu}$ durumda GBH sakinlerinin çok sayıda koyun ve/veya keçiden oluşan sürülere sahip oldukları söylenebilir. Bir topluluğun çok sayıda hayvana sahip olması ise, Susan D. De France'nin Zooarchaeology in Complex Societies: PoliticalEconomy, Status, and Ideology başlıklı makalesinde söz ettiği gibi ekonomik ve politik bir güç kazandırmaktadır. Bu da 
topluluklara statü olarak daha üstte olma imkanı sağladığı ifade edilmektedir. Buradan hareketle GBH sakinlerinin Demir Çağı'nda büyük hayvan sürüleri olan refah seviyesi yüksek bir topluluk olduklarını düşündürmektedir. İleride bölgede veya Gökhöyük Bağları Höyük'te yapılacak yeni kazılarda elde edilecek pişmiş toprak örneklerin veya Zooarkeolojik buluntuların bilimsel usullere göre yapılacak analizleri bu görüşlerimizi destekleyecek veriler sunacaktır.

\section{SUMMARY}

Gökhöyük Bağları Mound is located in the provincial borders of Konya, between Gökhöyük and Kesecik Villages in the south of Central Anatolia. The mound was established near water sources (on the shore of Lake Sugla, which was called Trigotis in antiquity) and near arable lands. In this study, a group of pottery exposed during $2002-2005$ the salvage excavations at Gökhöyük Bağları Mound, are the subject of this study. The finds unearthed in Gökhöyük show that the earliest inhabitants of the mound lived here during the Pottery Neolithic Period. There is a cultural continuity in the mound starting from the Neolithic Period to the Hellenistic and Roman Periods. This cultural continuity can be followed through the terracotta pottery uncovered. Due to the scratches on the inside of some of the pieces evaluated in this study and the finger-thick additions most probably added during the production stage before cooking the pots, these pots were evaluated in a separate group from other ceramics. As a result of the examinations and researches, it was realized that these ceramic pieces were terracotta pieces of churns (Turkish Yayzk). Churns are terracotta containers used to obtain butter from milk, or to make buttermilk; today, however, churn-making by hand has been abandoned with the inventing of automatic machines. The churns evaluated under two different groups are called horizontal and vertical churns. The earliest example of horizontal churns seen in Anatolia and dating back to the Chalcolithic Period, is on display at the Amasya Archeology Museum. Horizontally shaped churns dating to the Bronze Age were found in some settlements in western Anatolia. The earliest examples of vertical churns are exposed from Yarıkkaya and Çamlıbel Tarlasi in the north of Central Anatolia. The churn sample dating to the Bronze Age in Anatolia has not been identified yet. But there is a depiction of a woman who spread churn on a scene on the Inandık Vase dated to the Hittite Period. This shows that the widespread usage in the Hittite Period is known. Vertical churn dating to the Iron Age was found in the Kaman-Kalehöyük and Kusaklı-Sarisa settlements. The 60 pieces of churn chunks were determined among the ceramics exposed during the excavations at Gökhöyük Bağları Höyüğü between 2002 and 2005. It was observed that those artefacts were dark-surfaced, wheel-made and coarse wares. As a result of the examinations made using analogical methods, they can be dated to the Iron Age. In conclusion, this study is of great importance in terms of revealing the first archaeological data regarding the possibility of processing of milk in the south of Central Anatolia to obtain secondary products such as butter. In this way, this study provides a basis for easier dating of similar form of churns that may be discovered in the region in the future.

SEFAD, 2020; (43): 325-344 


\section{KAYNAKÇA}

Arbuckle S. B., Öztan, A., Gülçur, S., (2009) The Rise of Cattle Cultures in Bronze Age Anatolia. Anthropozoologia 44(1) 129-157.

Atıc1, L. (2014). The Secondary Products Revolution in light of textual evidence from Kültepe-Kanesh, central Turkey. (Ed.) H. Greenfieldpp, Animal Secondary Products: Domestic Animal Exploitation in Prehistoric Europe, the Near East and the Far East. (p. 233252) Oxford: Oxbow Books Press.

Ayverdi İ. (2011). Misalli Büyük Türkçe Sözlük. İstanbul: Milliyet Yay.

Cultraro, M. (2013). Barrel-Shaped vessels in context: A Long-Range model of dairy production in eastern and central Mediterranean during the late fourth and early third millennia BC., Origini Xxxv. 157-189.

De France, D. S., (2009) Zooarchaeology in Complex Societies: Political Economy, Status, and Ideology.Journal of Archaeological Research 17(2). 105-168. doi: 10.1007/s10814-0089027-1

Evershed, R.P. (1993). Biomolecular archaeology and lipids. World Archaeology, 25, 74-93. doi: 10.1080/00438243.1993.9980229

Evershed, R.P. Rayne, S., Sherratt, A.G., Copley, M.S., Coolıdge, J.,Urem-Kostu, D., Kotsakıs, K., Özdoğan, M., Özdoğan, A.E., Nieuwenhuyse, O., Akkermans, P.M.M., Barley, D., Andeescu,R., Campbell, S., Farıd, S., Hodder, I., Yalman, N., Özbaşaran, M., Bıçakcı, E., Garfınkel, Y., Levy, T., Burton, M.M. (2008). Earliest date for milk use in the Near East and Southeastern Europe linked to cattle herding. Nature, 455, 528-531. doi: 10.1038/nature07180

Gerritsen, F.A. Özbal R. (2011). Anadolu'da sütün tarih öncesi. Neolitik Barçın Höyük. Aktüel Arkeoloji Dergisi, 24, 40-41.

Gündüz, R. (2019a). Gökhöyük Bağları Höyüğü Demir Çağı Seramiği. (Doktora Tezi). Selçuk Üniversitesi, Konya.

Gündüz, R. (2019b). Gökhöyük Bağları Höyüğünden Erken Demir Çağı seramiği. Karadeniz Uluslararası Bilimsel Dergi, 42, 204-222. doi: 10.17498/kdeniz.520614

Gündüz, R. (2019c) Gökhöyük Bağları Höyüğünden Bir Grup Akhaimenid Kase. (Ed.) A. Erön \& E. Erdan, Doğudan Batıya 70. Yaşında Serap Yaylalı'ya Sunulan Yazılar. (s. 465-484) Ankara: Bilgin Kültür Sanat Yay.

Gündüz, R. (2019d) Lykonia Bölgesinde Yeni Bir Yerleşme, Gökhöyük Bağları Höyügü̈. (Ed.) H. Muşmal \& E. Yüksel \& M. A. Kapar, Karaman Araştırmaları I. (s. 41-52) Konya: Palet Yay.

Hendy, J., Colonese, A.C., Franz, I., Fernandes, R., Fischer, R., Orton, D., Lucquin, A., Spindler, L., Anvari, J., Stroud, E., Bieh, P. F., Speller, C., Boivin, N., Mackie, M., JersieChristensen, R. R., Olsen, J. V., Collins, M. J. Craig, O. E., Rosenstock. E. (2018). Ancient proteins from ceramic vessels at Çatalhöyük West reveal the hidden cuisine of early farmers. Nature Communications, 4064, 1-10. doi: 10.1038/s41467-018-06335-6

Itan, Y., Powell, A., Beaumont, M. A., Burger, J., Thomas, M. G. (2009). The origins of lactase persistence in Europe. PLoS Computational Biology, 5/8 1-13. doi: 10.1371/journal.pcbi.1000491

James, F. (1975). Yogurt: its life and culture. Expedition, 18, 32-45.

Karpuz, H., Ürekli, B., (2011). Konya ve Çevresinde Geleneksel Yayık Tipler. (Haz.) Şener, T., Erdoğan, M. A., Müjgân Üçer'e Armağan, (s.169-179) İstanbul: Kitabevi Yay.

Larson, G., Fuller, D.Q. (2014). The Evolution of Animal Domestication. Annual Review of Ecology, Evolution, and Systematics, 45, 115-136. doi: 10.1146/annurev-ecolsys-110512135813

Matsumura, K. (2005). Die Eisenzeitliche keramik in Zentralanatolien aufgrund der keramik in Kaman-Kalehöyük. (Doktora Tezi). Freie Universitet, Berlin. 
McCormick, F. (2012). Cows, milk and religion: the use of dairy produce in early societies. Anthropozoologica, 47/2, 101-113. doi: 10.3168/jds.S0022-0302(07)71632-6

Morris, S. P. (2013). From Clay to Milk in Mediterranean Prehistory: Tracking a Special Vessel. (Ed.) G. E. Areshia, Celebrating 40 Years of Discovery, (p. 70-79) Los Angeles: Annual Reviev of The Cotsen Institüte of Archaeology at Ucla

Morris, S. P. (2014). Dairy Queen: Churns and milk products in the Aegean Bronze Age. Opuscula, 7, 205-222.

Okan, E., (2013). Çeşme Müzesi'nde Bulunan Yayık Amphora Üzerine Düşünceler. OLBA XXI, 101-109.

Ökse, A.T. (2002). Gre Virike 2000 kazısı. (Ed.) N. Tuna \& J. Velibeyoğlu, Ilısu ve Karkamış baraj gölleri altında kalacak arkeolojik ve kültür varlıklarını kurtarma projesi 2000 yılı çalışmaları. (s. 241-269) Ankara: TAÇDAM

Özbal, H., Türkekul Bıyık. A., Thissen. L. , Doğan. T., Gerritsen F., Özbal. R. (2011). Sütçülerin Öncüleri: Barcın Höyük Keramiklerinde Süt Kalıntıları. Arkeometri Sonuçları Toplantısl, 26, 307-317.

Özgüç, T. (1988). İnandıktepe - Eski Hitit Çağında Önemli Bir Kült Merkezi - İnandiktepe - An Important Cult Center In The Old Hitite Period. Ankara: T.T.K.

Powroznik, K. (2008). Vessels for Milk Processing from Kaman-Kalehöyük And Kuşaklı. Anatolian Archaeological Studies, 17, 225-231

Salque, M., Bogucki, P. I., Pyzel, J., Sobkowiak-Tabaka, I., Grygiel, R., Szmyt, M., Evershed, R. P. (2013). Earliest evidence for cheese making in the sixth millennium BC in northern Europe. Nature, 493(7433), 522-525. doi: 10.1038/nature11698

Sauner, M. H. ( 2018). Süt ürünleri gelenekleri üzerine (20. yüzyıl Çivril ve Akçakoca örneği) Yemek ve Kültür, 53, 9-22

Sauter, F., Puchinger. L., Schoop. U.-D., (2003). Studies in organic archaeometry VI. Fat analysis sheds light on everyday life in prehistoric Anatolia: traces of lipids identified in chalcolithic potsherds excavated near Boğazkale, Central Turkey. ARKIVOC, 15, 15-21. doi: 10.3998/ark.5550190.0004.f03

Schoop, U.-D. (1998). Anadolu'da Kalkolitik Çağda Süt Ürünleri Üretmi. Bir Deneme. Arkeoloji ve Sanat Dergisi, 87, 26-32.

Schoop, U.-D. (2017). Innovation versus beharrung: was macht den unterschied des Hethitischen reichs im Anatolien des 2. Jahrtausends v. Chr.? (Ed.) A. Schachner. Technologie und innovation im anatolischen chalkolithikum. internationaler workshop zu ehren von Jürgen Seeher. (p. 1-19) Istanbul: Ege Yay.

Sherratt, A. G. (1981). Plough and pastoralism: aspects of the Secondary Products Revolution. (Ed.) I. Hodder, G. Isaac and N. Hammond, In Pattern of the Past (p. 261-336) Cambridge: Cambridge University Press.

Şenel, E., Atamer, M., Öztekin, Şebnem. (2010). Yayıklama Parametrelerinin Yayık Ayranı Ve Yayık Tereyağının Bazı Nitelikleri Üzerine Etkisi. Gıda, 35, 267-274.

Takaoğlu, T. (2006). Patterns of dairying in coastal Northwestern Anatolia. (Ed.) T. Takaoğlu. Ethnoarchaeological Investigations in Rural Anatolia, 3, (23-44) İstanbul: Ege Yay.

Trbojević-Vukičević, T., Marenjak, S. T., Kužir1, S., Čataj. L. (2011). Arheological and archaeozoological evidence of milk as a food in the territory of Croatia. Mljekarstvo, 61/4, 319-325. doi: 10.15567/mljekarstvo. 


\section{FİG̈̈RLER}

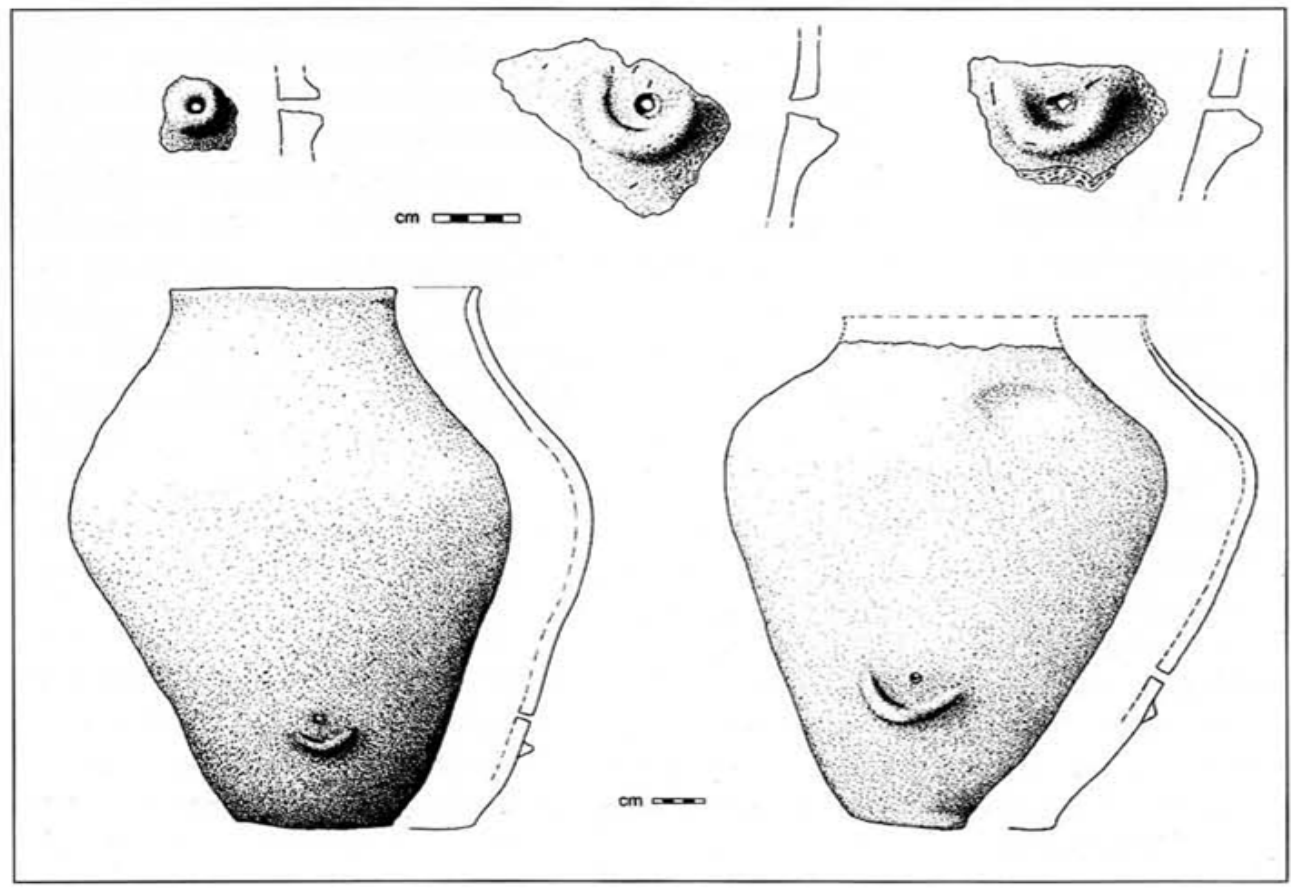

Şekil 1: Yarıkkaya' dan Kalkolitik Döneme ait akıtacaklı kaplar. (Schoop 1998, p. 28).

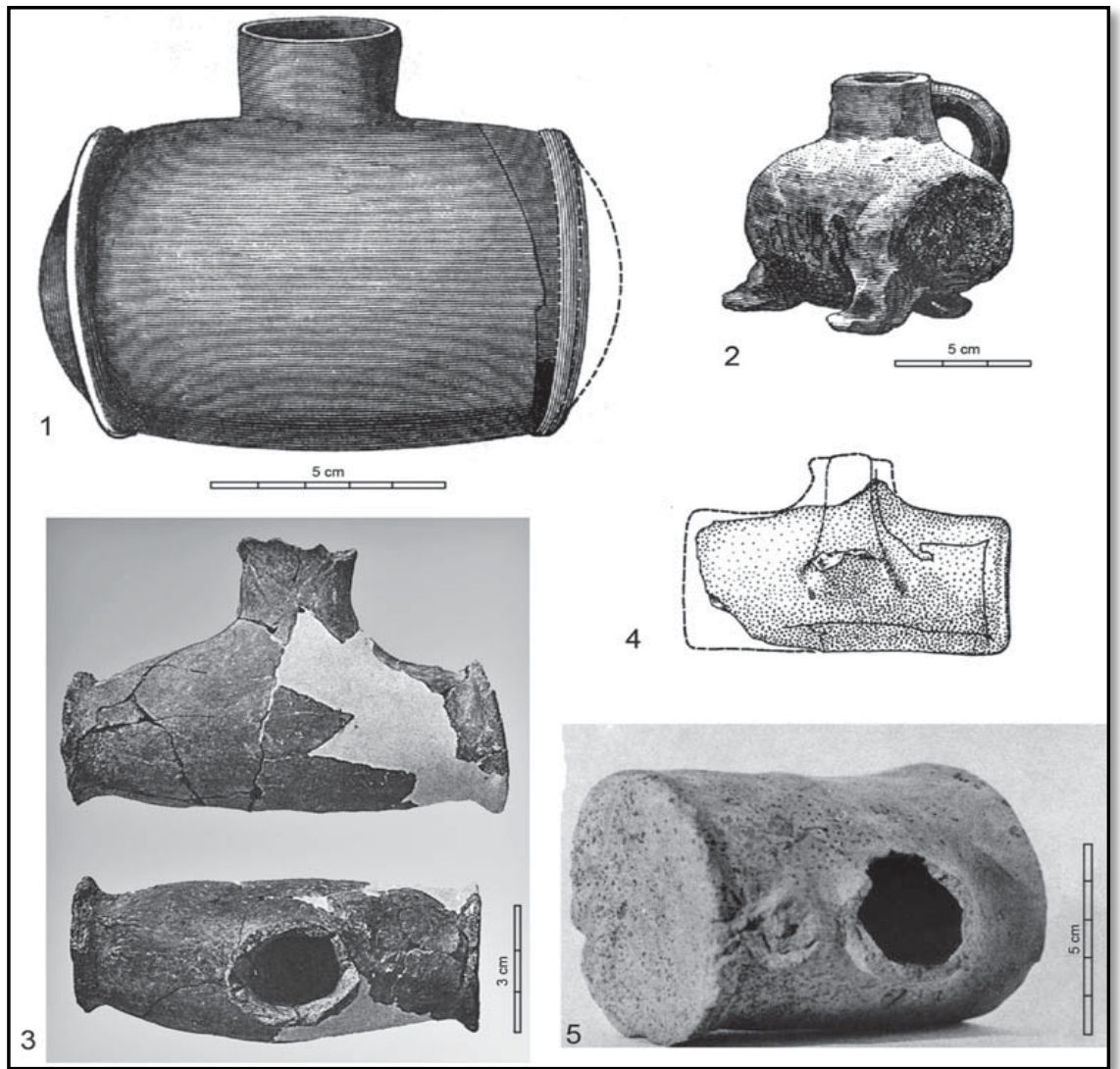

Şekil 2: Tunç Çağına tarihlenen batı Anadolu'da yayık örnekleri. Truva 1-3, Kaklık Mevkii 4., Karataş 5. (Cultraro, 2013, p. 157-189). 


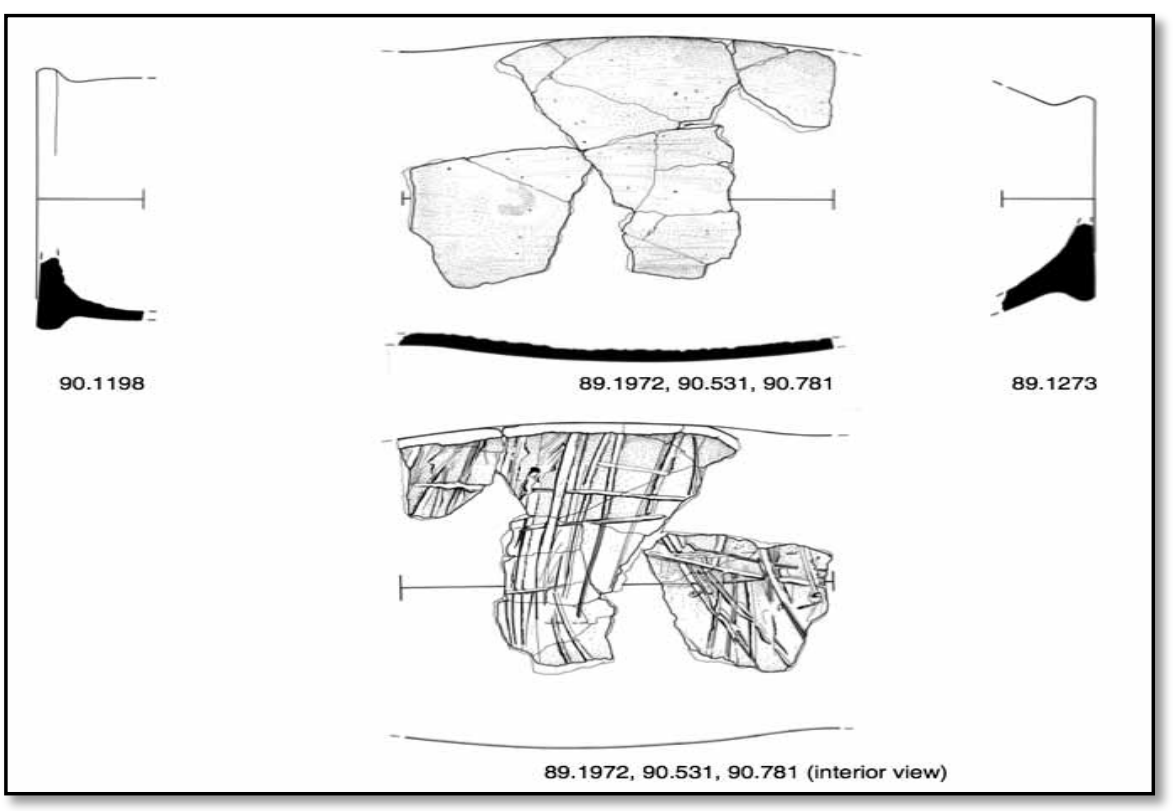

Şekil 3: Halkidiki'den Tunç Çağına tarihlenen yatay yayık. (Morris, 2013, p. 70-79).
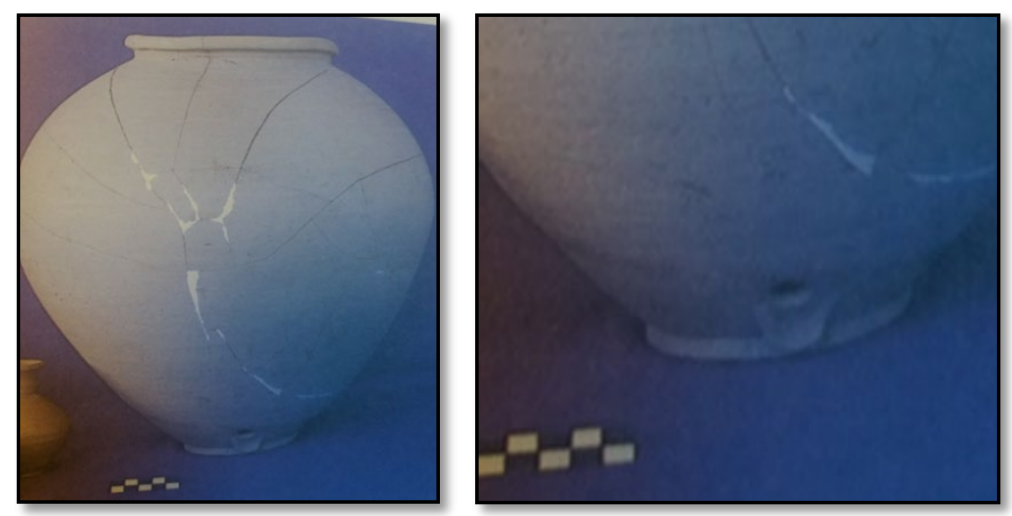

Şekil 4: Gre Vrike'den ETC III'e tarihlenen akıtacaklı kap. (Ökse, 2002, s. 267).
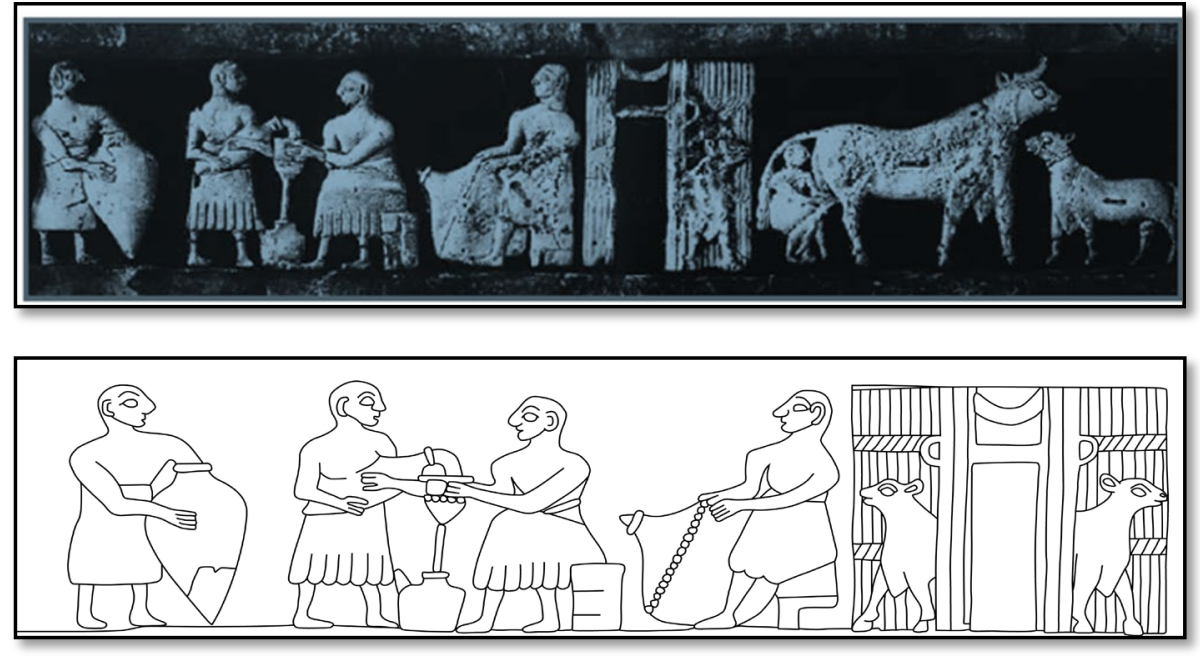

Şekil 5: Ninhursag Tapınağındaki süt sağımı ve sütün işlenmesinin anlatıldığı frizler (McCormick, 2012, p. 101-113). 


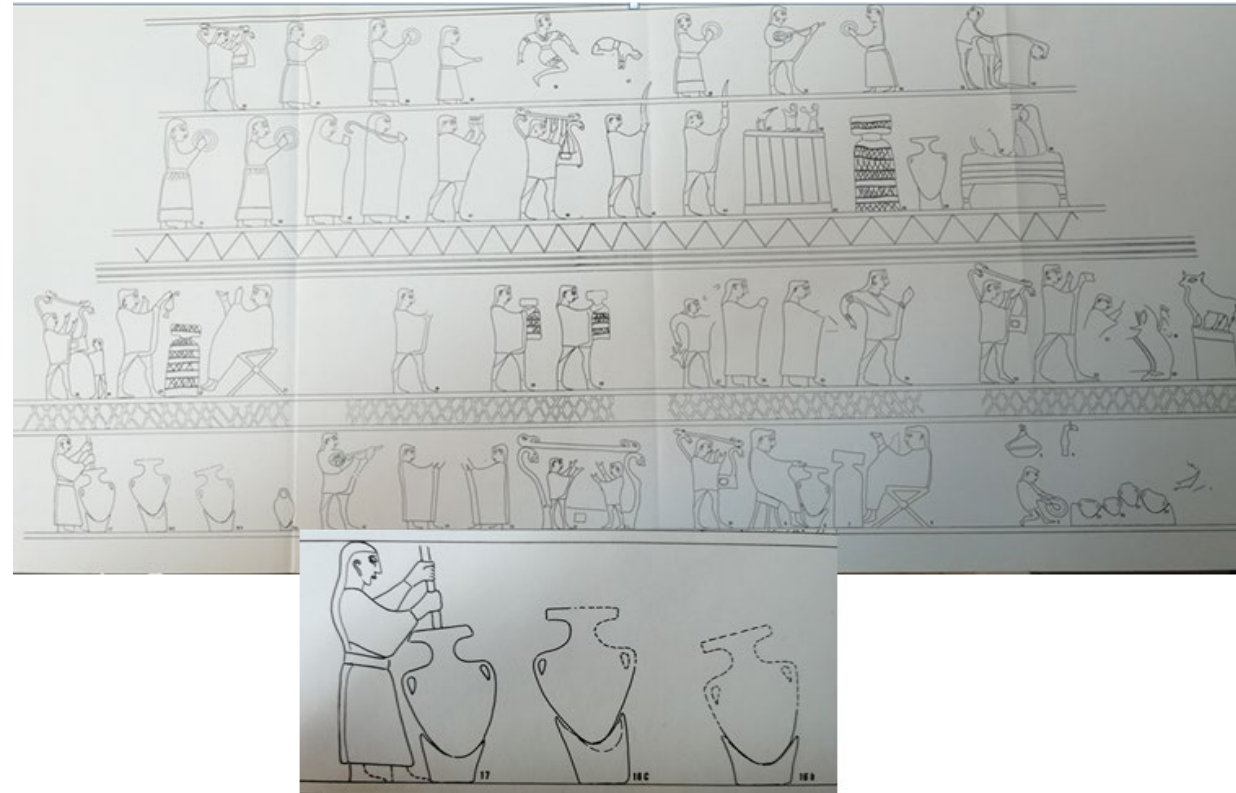

Şekil 6: İnandık vazosu üzerinde anlatılan sahnelerde yayık betimlemesi. (Özgüç, 1988, s.175, Fig. 65. Lev. 44,).

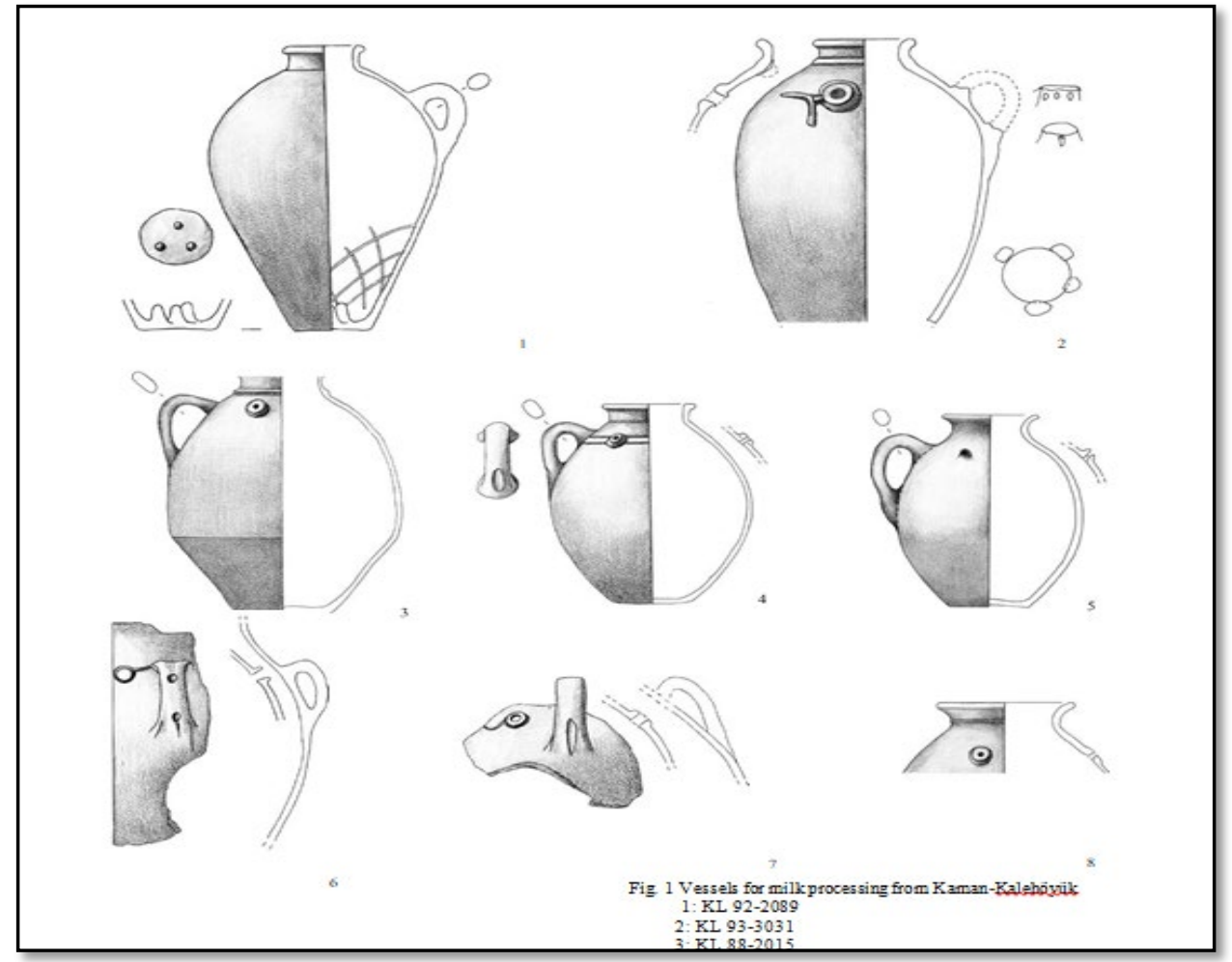

Şekil 7: Kaman-Kale Höyük'ten yayık örnekleri. (Prowznik, 2008, p. 225-231). 

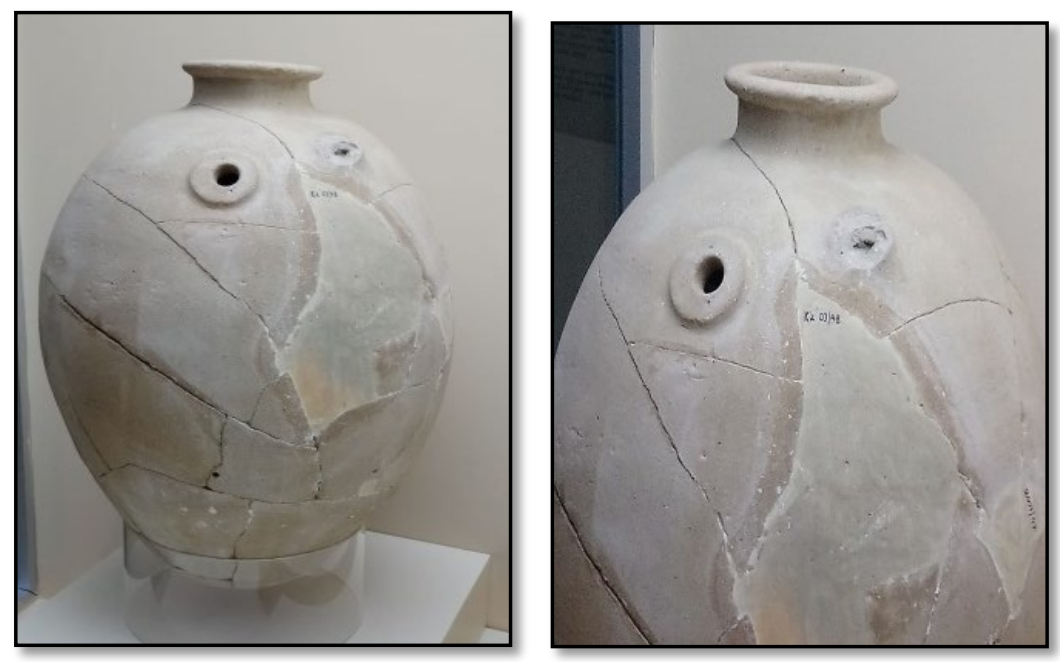

Şekil 8: Sivas Arkeoloji Müzesi teşhir salonunda sergilenen Kuşaklı yerleşmesinden yayık kabı.

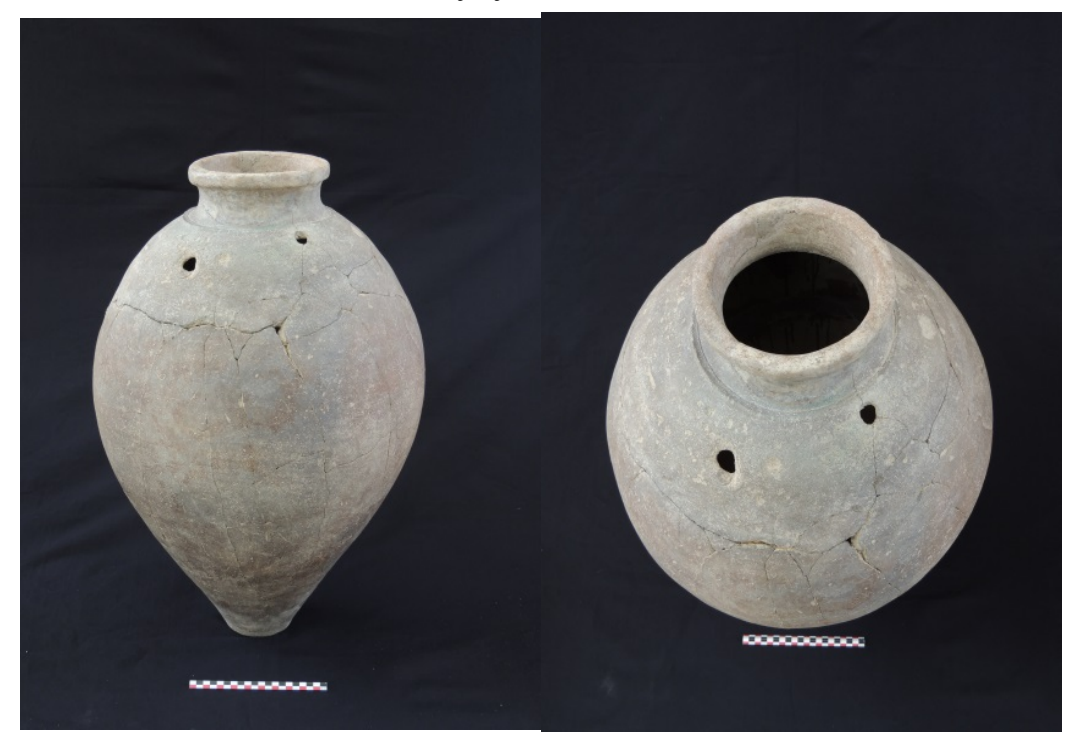

Şekil 9: 2018 yılı Maydos Kilise Tepe kazılarında bulunan yayık kap. (Fot. Göksel SAZCI)

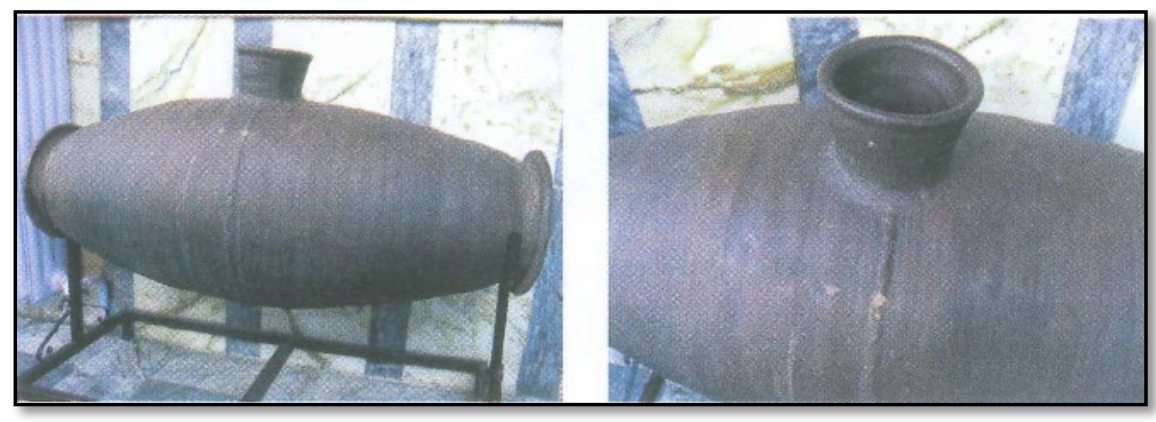

Şekil 10: Yatay yayık, günümüz örneği. (Karpuz ve Ürekli, 2011, s. 175). 
Şekil 11: Amasya Arkeoloji Müzesinde bulunan Kalkolitik Dönem yatay yayık kap.

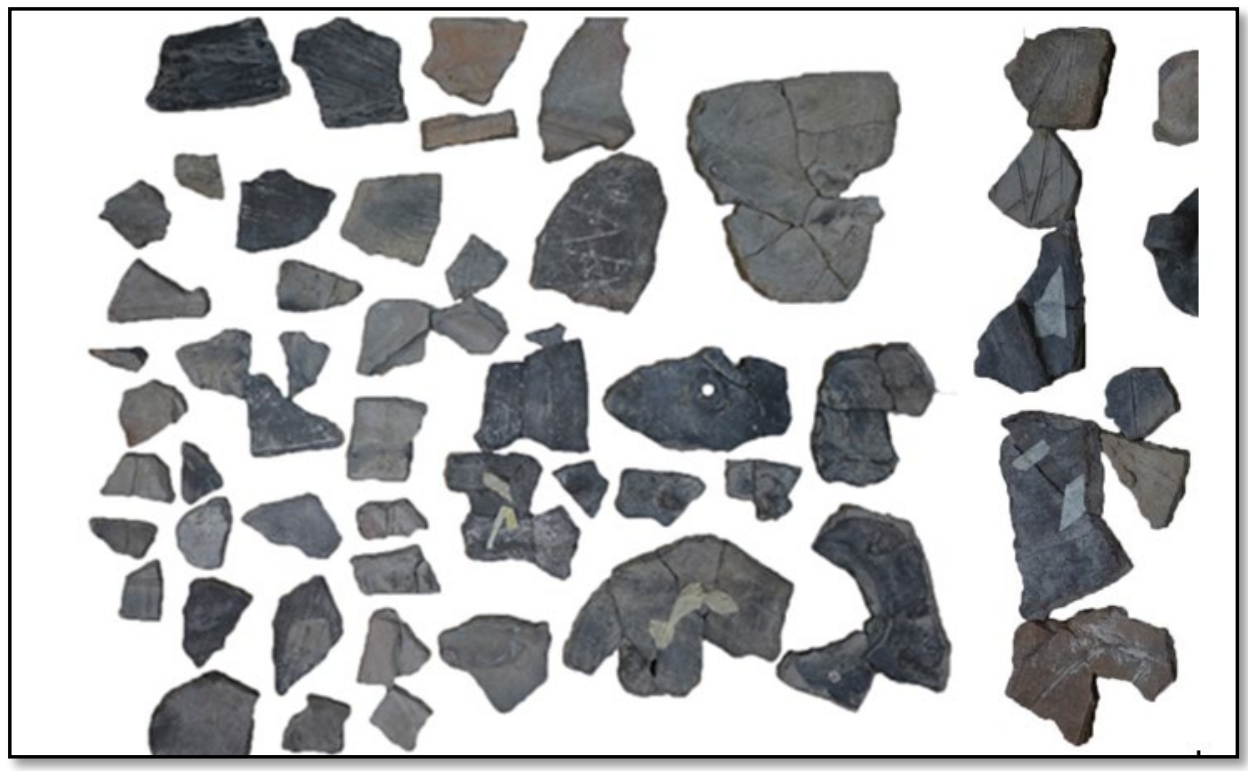

Şekil 12: Gökhöyük Bağları Höyüğü yayık kap parçaları.

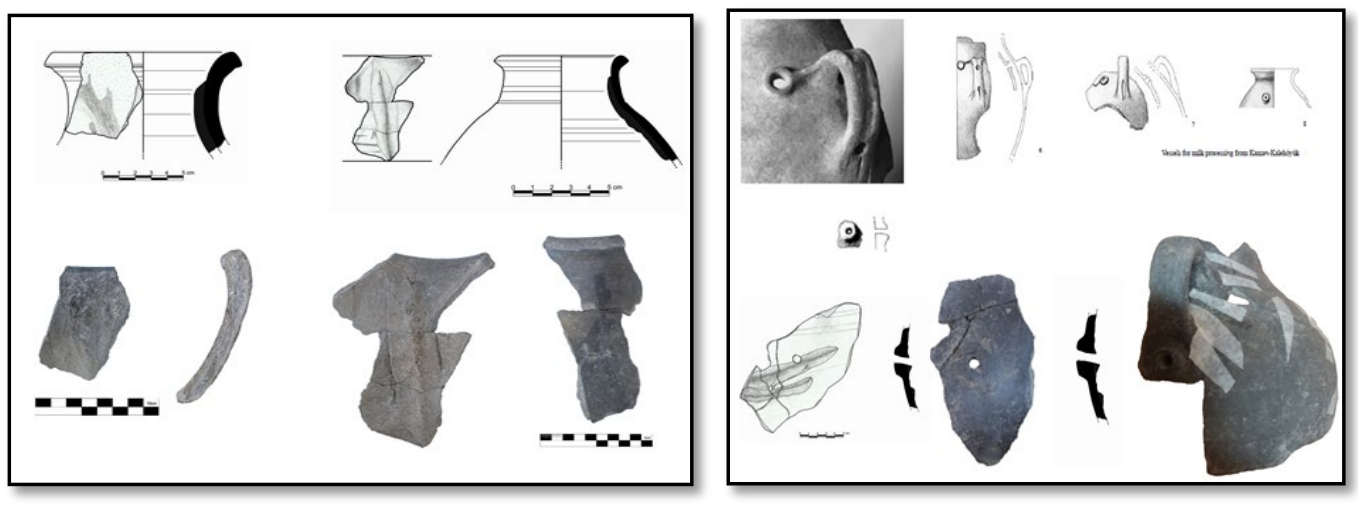

Şekil 13: Gökhöyük Bağları Höyüğü yayık ağız kenarı ve kulp örnekleri. 


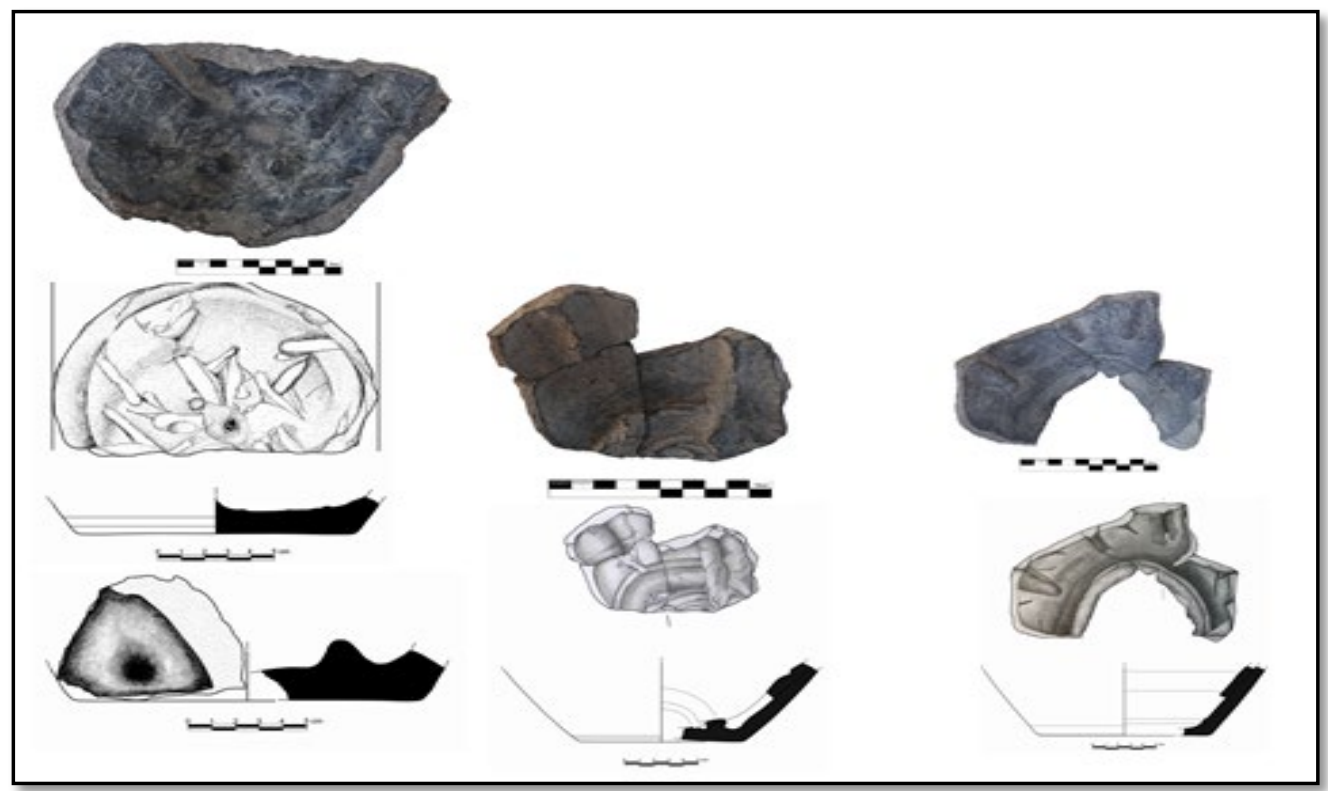

Şekil 14: Gökhöyük Bağları Höyüğü yayık kap dip (kaide) örnekleri.

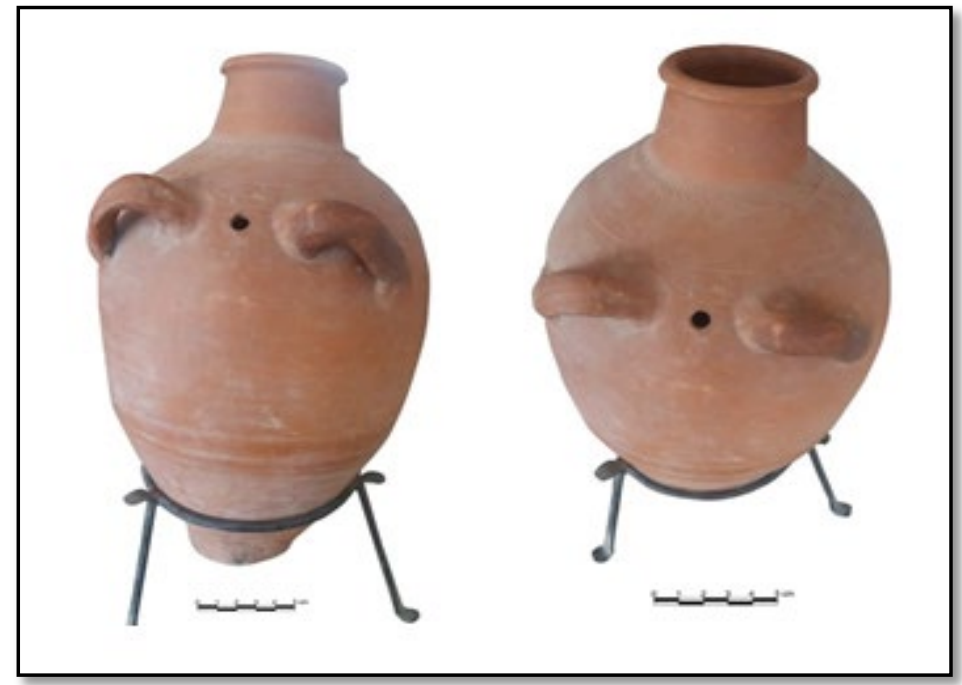

Şekil 15: Günümüz dikey yayık örneği.

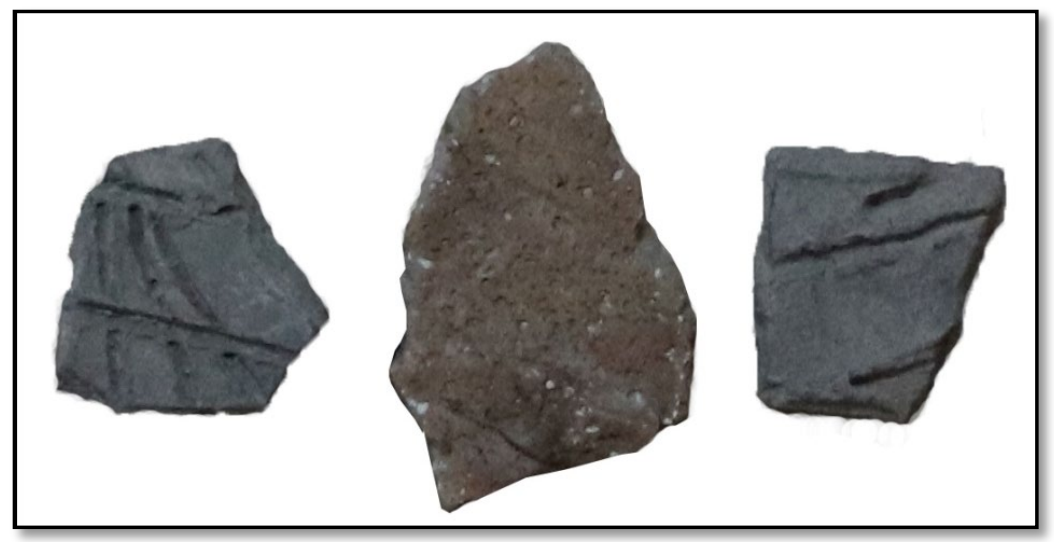

Şekil 16: Gökhöyük Bağları Höyüğü yayık gövde parçaları. 


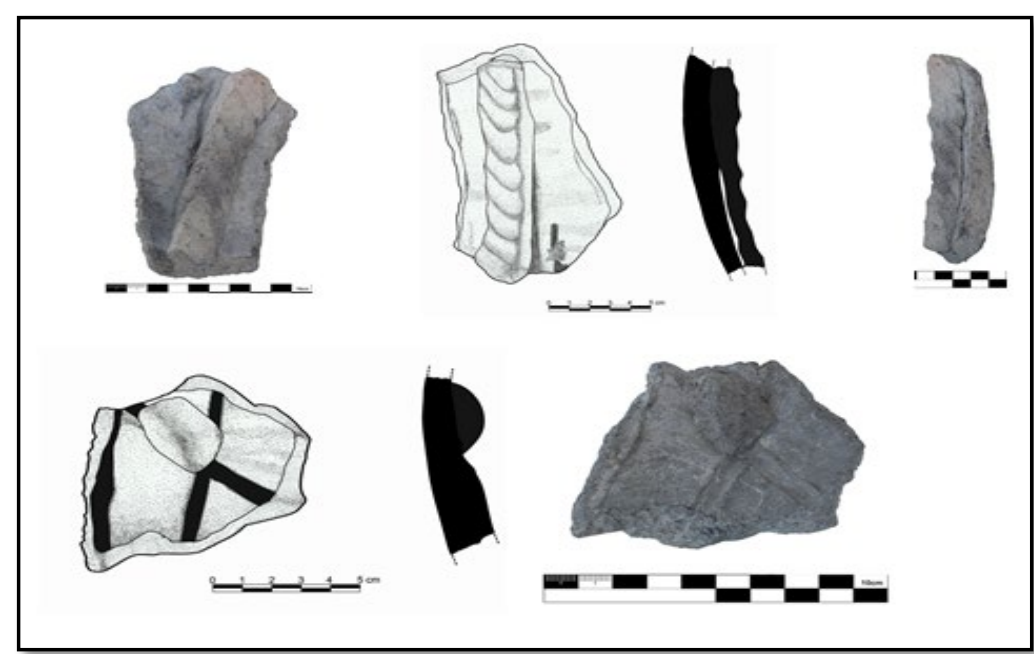

Şekil 17: Gökhöyük Bağları Höyüğü yayık gövde parçaları. 